\title{
NOVÁ KNIHA O MEZINÁRODNÍ MĚNOVÉ A FINANČNÍ STABILITĚ
}

\section{Jana Markováa}

Petr Sedláček: Zapojení České republiky do mezinárodního úsilí o posílení globální měnové a finanční stability

Praha: Grada Publishing, 2020. 1. vydání, 176 stran. ISBN 978-80-271-1737-6.

Po celou novodobou historii jsme svědky snahy mezinárodního společenství o posílení globální měnové a finanční stability. S určitou nadsázkou by se dalo říci, že díky krizím se podařilo v této oblasti dosáhnout určitých změn. Stačí se podívat na dluhovou krizi z 80. let 20. století, na novou generaci finančních krizí v 90. letech, na globální finanční krizi v letech 2008/2009 a v neposlední řadě i na vývoj současné koronavirové krize.

Recenzovaná publikace seznamuje čtenáře $\mathrm{s}$ tím, co se podařilo zrealizovat $\mathrm{v}$ oblasti posilování měnové a finanční stability, hodnotí účinnost přijatých opatření i možné cesty jejich dalšího zkvalitnění a rovněž ukazuje, jak se na tomto mezinárodním úsilí podílí Česká republika. Autor touto knihou fakticky navazuje na svoji publikaci Mezinárodní měnový systém a globální finanční krize z roku 2018, ve které popsal jednotlivé oblasti mezinárodního měnového systému, kam reformní úsilí po globální finanční krizi 2008/2009 směřovalo.

Z hlediska formálního je monografie členěna do sedmi kapitol, ve kterých jsou sledované události popisovány jednak v historických souvislostech, ale také, a to především, z pohledu našich aktuálních zájmů. To umožňuje čtenáři lépe pochopit důvody našich aktivit a postojů $\mathrm{k}$ navrhovaným opatřením.

V době uzávěrky textu knihy propukla koronavirová krize, která způsobila obrovské zdravotní, ekonomické a finanční problémy prakticky všem zemím po celém světě. Nutná opatření k omezení širření viru se projevila v dramatickém poklesu ekonomické aktivity. Tam, kde je to možné, autor uvádí některá přijímaná opatření, která se však stále mění a jejich zachycení není snadné. Protože konečný dopad krize i doba př́ípadného ekonomického oživení jsou velmi nejisté, ztížilo autorovi možnost efektivního zhodnocení těchto 
opatření, proto by bylo žádoucí se $\mathrm{k}$ této problematice $\mathrm{v}$ budoucnu vrátit a realizovaná opatření vyhodnotit z pohledu jejich př́nosu pro nastartování ekonomik zemí postižených krizí.

V první kapitole je pozornost věnována formám zapojení České republiky do globálního governance. Dobře fungující mezinárodní měnový a finanční systém (MMS) musí být podpořen legitimní a efektivní strukturou správy a řízení. Autor se zaměřje na dvě klíčové instituce - Mezinárodní měnový fond (MMF) a skupinu G-20.

Kapitola začíná exkurzem do předválečného období, kdy začala jednání o poválečné mezinárodní měnové spolupráci. Tato jednání vedla $\mathrm{k}$ založení dvou nadnárodních institucí, a to Mezinárodního měnového fondu a Mezinárodní banky pro obnovu a rozvoj (Světová banka), jejichž úkolem bylo dohlížet nad dodržováním dohodnutých principů mezinárodní měnové spolupráce. Autor tu seznamuje čtenáře s našim zapojením do probíhajících jednání a následně hodnotí pozici, ve které se Československo nacházelo od počátku fungování MMF až do ukončení našeho členství v roce 1954, a to z důvodu neplnění povinností vyplývajících z Dohod o založení MMF, především neochotu poskytovat informace o stavu ekonomiky. Velkou pozornost věnuje autor našemu obnovenému členství v roce 1990 a otázce rozdělení kompetencí mezi centrální bankou a Ministerstvem financí ohledně zastupování ČSFR v MMF a Světové bance a následně i změnám, ke kterým v této oblasti došlo po rozdělení Československa.

V další části první kapitoly se autor zabývá naším vztahem k MMF, kde jsme se stali velmi brzy jeho plnohodnotným členem. Postupně seznamuje čtenáře s našimi aktivitami a našim zapojením do řídících struktur této instituce, prričemž využívá svých poznatků, získaných z doby svého působení v ČNB jako experta pro spolupráci s MMF. Čtenáŕ tak má možnost se seznámit s fakty, která nejsou běžně dostupná. Autor tu popisuje složitost jednání o zastoupení Evropské unie v MMF. Tlaky na snížení zastoupení EU ve Výkonné radě nakonec přispěly $\mathrm{k}$ vytvoření středo- a východoevropské konstituence, jejíž jsme členem a poprvé v novodobé historii ČR (po roce 1990) jsme měli možnost obsadit v období 2016-2018 pozici výkonného ředitele. Po J. V. Mládkovi a B. Suchardovi (kteří nás zastupovali v Radě výkonných ředitelů v letech 1945/1954) to byl historicky náš třetí výkonný ředitel v MMF. Zvýšením úrovně zastoupení v MMF se nepochybně, jak zdůrazňuje autor, zvyšuje i reputace ČR a její formální i neformální vliv na dění nejen v naší konstituenci, ale i na celé správě a řízení MMF. Změny v zastoupení EU ve Výkonné radě, které autor popisuje, jsou ale pouze malým krokem na cestě k reformě governance, kterou MMF potřebuje. Další kroky by měly následovat, a to tak, aby řizení MMF lépe odráželo ekonomickou sílu a potenciál nově se rozvíjejících zemí a současně omezilo doposud dominantní postavení ekonomicky vyspělých zemí na jeho správě a rozhodování. Reformován by měl být i mechanismus jmenování generálního ředitele MMF, nebot' stávající systém pouze přispívá ke ztrátě důvěryhodnosti a podlamuje legitimitu této instituce. Této 
otázce se autor věnuje v další části kapitoly, když ilustruje na snahách některých zemí změnit tento status quo, $\mathrm{k}$ čemuž zatím chybí dostatečná politická vůle. Závěr první kapitoly je věnován vztahům ČR se skupinou G-20, kde, jak uvádí autor, jsme na rozdíl od naší pozice v MMF pouze př́ijemcem informací. Naší jedinou aktivitou je účast na př́ípravě stanovisek EU, která jsou zpracovávána ve spolupráci s Evropskou komisí v rámci Evropské rady, $\mathrm{ECOFINu}^{1}, \mathrm{EFC}^{2}$ a SCIMF${ }^{3}$. Tyto materiály pak slouží jako poziční dokumenty. Ponechává se $\mathrm{v}$ nich sice určitý manévrovací prostor pro zástupce EU, aby byli schopni operativně a kvalifikovaně reflektovat na vývoj diskuse a dospět ke kompromisu. Ne vždy se to však podle autora daří. V době našeho předsednictví v Radě EU, v roce 2009, jsme měli možnost se zapojit i do práce odborných podvýborů a účastnit se vrcholových setkání skupiny G-20. Tím jsme získali cenné zkušenosti, které bude nepochybně možné uplatit při našem druhém předsednickém angažmá v Radě EU v roce 2022. Vzhledem k tomu, že jsme malá země, bylo by chybné si myslet, jak uvádí autor, že můžeme v globální governanci působit jako nějaká supervelmoc, a proto je nutné pro podporu našich stanovisek hledat další státy se shodnými pozicemi a vytvářet formální, nebo ad-hoc koalice, a to nejen v rámci Evropské unie.

Druhá kapitola se věnuje dohledu MMF a př́stupu ČR k této problematice. Autor tu rozebírá nové dohledové priority MMF, které jsou reakcí na období globální finanční krize, která odhalila neefektivnost dosavadního dohledu a neschopnost včas rozpoznat postupně nahromaděná rizika. Efektivnost dohledu MMF však závisí též na tom, do jaké míry budou jednotlivé země ochotny jeho doporučení realizovat, a tedy na důvěře v tuto instituci. Autor zde zřejmě nechtěl zacházet do větších podrobností, když zdůraznil především aspekt zvýšení legitimity MMF, která by měla posílit jeho autoritu a důvěryhodnost. Bylo by možné uvést i další opatření, případně se zamyslet nad tím, zda je lepší prosazovat doporučení dohledu na dobrovolné bázi nebo pomocí mimořádných konzultací, či dokonce sankcí, které ale ČR nepodporuje. Vzhledem k tomu, že vůči MMF nemáme žádné závazky z půjček, jsou pro nás doporučení MMF nezávazná. Nicméně autor poukazuje na to, že vzájemný dialog nám pomáhá upřesnit a vyjasnit si naše postoje ke specifickým otázkám, a že se často stal i impulzem k zásadnímu rozhodnutí, jakým bylo např́klad stanovení výše kurzu na začátku reforem v roce 1990 nebo nahrazení kurzové kotvy inflačním cílováním v roce 1997. Dnes jsme zapojeni ve všech zásadních dohledových aktivitách MMF, jako jsou $\mathrm{FSAP}^{4}$ a $\mathrm{ROSC}^{5}$, rovněž poskytujeme vyžádaná data

\footnotetext{
1 Economic and Financial Affairs Council.

2 Economic and Financial Committee.

3 Podvýbor EFC pro MMF.

4 Financial SectorAssessment Program.

5 Reports on the Observance of Standards and Codes.
} 
a účastníme se povinných A-IV konzultací. To má pozitivní dopad nejen na národní úrovni, ale i na naše hodnocení ze strany ratingových agentur a zahraničních investorů, kteří pravidelně informace o jednotlivých státech čerpají z MMF. K doporučení MMF na řešení problémů členských zemí by bylo možné namítnout, že ne vždy taková doporučení jsou hodnocena ze strany prijímajících zemí pozitivně. Návrhy na řešení měnové krize, která u nás propukla v roce 1997, patří právě mezi ty kontroverzní. Tehdy nám MMF doporučoval další zvyšování úrokových sazeb (jako podmínku pro budoucí pomoc) místo obvyklé devalvace, kterou situace v době vysokých úrokových sazeb a fixního kurzu, vyžadovala.

Třetí kapitola se zaměřje na kurzy a kurzové režimy. Kurzové režimy sice leží v samém jádru mezinárodního měnového systému, ale ekonomové nemají jednoznačnou odpověd’ na otázku, jaký kurzový režim by byl optimální. Ke stabilitě MMS by mohlo přispět respektování určitých zásad při jejich výběru. Uplatňovaný kurzový režim by měl vést $\mathrm{k}$ dosažení domácích makroekonomických cílů (cenová stabilita a udržitelný růst), k plynulému přizpůsobování vnějších nerovnováh a $\mathrm{k}$ podpoře zahraničněobchodní spolupráce. Jak autor uvádí, MMF v tomto ohledu nemůže př́iliš do výběru zasahovat, ale může monitorovat konsekvence tohoto výběru a př́ípadně doporučovat vhodnější režimy. Snad nejvíce diskutovaným aspektem MMS je vývoj kurzů hlavních mezinárodních měn. Důležitým předpokladem dobře fungujícího MMS jsou totiž kurzy, které budou v rozumné míre stabilní a v souladu s ekonomickými fundamenty. Od r. 1973 jsme však svědky toho, že kurzy hlavních měn široce fluktuovaly, což bylo sice částečně odrazem spekulativních útoků, ale především vychylováním kurzů od ekonomických fundamentů. Autor konstatuje, že v důsledku neexistence jednotně uznávaného modelu pro stanovení optimální úrovně kurzu, MMF svá doporučení nemůže efektivně prosazovat. Může pouze sledovat členské země a vyhodnocovat a poskytovat informace o potenciálních dopadech jejich kurzové politiky. Ǩada ekonomů proto navrhovala zavést určité normy či hranice, mezi kterými by se mohly kurzy pohybovat. Ale tento názor nebyl členskými státy akceptován. Čtenář má možnost se seznámit s tím, jak oficiální měnové autority rozhodovaly o volbě kurzových režimů v průběhu naší novodobé historie a jaké důvody je $\mathrm{k}$ tomu vedly. V určitých etapách vývoje jsme byli svědkem aktivního nastavování kurzu národní měny, což autor demonstruje na fixním kurzovém režimu v letech 1991-1997, ř́zeném a volném floatingu v letech 1997-2013 a kurzu jako doplňujícího nástroje měnové politiky v období 2013-2017, až po současnost.

Autor zde také připomíná významnou událost z roku 1995, kdy jsme se přihlásili k článku VIII Dohody o MMF, ze kterého vyplývá pro členské země povinnost odstranit devizová omezení na všechny transakce běžného účtu platební bilance. Česká koruna se tak od 1. října 1995 stala směnitelnou měnou a Česká republika tím vyslala mezinárodní komunitě signál, že bude pokračovat v realizaci zdravé hospodářské politiky, která 
jí umožní vyhnout se restrikcím a tím přispívat $\mathrm{k}$ vytvoření volného multilaterálního platebního systému.

Kapitola čtvrtá se zaměřuje na kapitálové toky. Hlavní výzvou dneška je, jak posílit jejich pozitivní dopady a přitom zabránit rizikům finanční nestability a neudržitelného růstu. Velké a nekontrolované kapitálové toky byly př́činou volatility měnových veličin, vyvolávaly nadměrnou akumulaci rezerv a byly zdrojem bezprecedentního růstu úvěrů a cen. Výsledkem tohoto vývoje byly a jsou opakující se finanční krize. Podle zakladatelů MMF obavy ze spekulativního pohybu kapitálu, přispívajícího k nestabilitě, vyžadovaly jejich kontrolu ze strany jednotlivých členských zemí. Ve druhé polovině devadesátých let minulého století však MMF začal uvažovat o rozšiřrení původního mandátu o liberalizaci kapitálových toků, což by znamenalo, že členské země by nemohly uvalovat restrikce na určitý typ kapitálových toků bez souhlasu MMF. Tato reforma se nakonec neuskutečnila především proto, že klíčové členské země nechtěly ztratit svoji suverenitu v této důležité oblasti, což bylo též spojeno s přesvědčením, že asijská krize měla svoje kořeny právě $\mathrm{v}$ předčasné liberalizaci finančního účtu. $\mathrm{V}$ reakci na tuto událost MMF zmírnil svoji dlouhodobou podporu neomezenému kapitálovému pohybu a akceptuje právo zemí chránit se před negativními důsledky volatility kapitálových toků, dokonce i kapitálovou kontrolou. Proto, jak uvádí autor, hlavním úkolem MMF v této oblasti bude pouze monitorování vývoje pohybu kapitálu a přijímání opatření a předkládání doporučení členským zemím. Česká republika ve svém př́stupu k řešení této problematiky vychází podle autora z toho, že liberalizovala i finanční účet již v období let 1995-1999 v rámci procesu vstupu a členství v OECD. Proto úsilí MMF o postupnou liberalizaci kapitálových toků nezpochybňuje, nebot' to pro nás neznamená žádné nové povinnosti. Podle autora je $\mathrm{v}$ dlouhodobém horizontu žádoucí, aby MMF získal mandát nad finančním účtem platební bilance. Argumentuje tím, že MMF je nesporně jediná instituce s univerzální členskou základnou, která má dostatečné odborné a technické kapacity k efektivnímu dohledu nad kapitálovými toky. Je proto racionální, aby MMF tyto toky monitoroval, analyzoval a doporučoval řešení. Dodává však, že zatím není pro tuto aktivitu dostatečná podpora ze strany členské základny. Současně však akcentuje nutnost zachování dobrovolnosti, nebot’ státy postižené nadměrnými př́livy či odlivy kapitálu musí mít možnost tyto toky regulovat, a to včetně zavedení jejich kontroly.

Zajímavou podkapitolou je restrukturalizace státního dluhu. Předpokladem efektivního fungování MMS je poskytovat mechanismus pro řešení nadměrného zadlužení státu s jasnými ex ante pravidly. Čtenář má možnost se seznámit s vývojem této problematiky i s posledními návrhy a možnostmi MMF podílet se na řešení problémů zemí s neudržitelným dluhem. V této souvislosti autor uvádí naše snahy o zefektivnění rámce pro zapojení MMF do řešení této problematiky s cílem zajištění včasné angažovanosti MMF 
a adekvátnosti doporučených postupů restrukturalizace dluhu, které by měly přispět k jeho udržitelnosti. Pozornost je věnována doložkám o společném postupu a vyjasnění účasti veřejného sektoru. Aktuálnost a naléhavost řešení této problematiky autor dokumentuje na současné situaci, kdy se po vypuknutí koronavirové krize MMF společně se Světovou bankou okamžitě zapojily do mezinárodního úsilí o odložení dluhů nejchudším zemím ze strany oficiálních věritelů.

Pátá kapitola se zaměřuje na globální sít' finanční záchrany (GFSN). V době krize se z finančních trhů doslova „vypařila likvidita“ a finanční zprostředkovatelé a centrální banky po celém světě usilovně hledaly „tvrdou“ měnu. Jedním ze základních úkolů MMS, který by zajistil jeho požadovanou stabilitu, se proto stalo zpř́stupnění likvidity zemím, které čelí jejímu dočasnému výpadku. Jako jednu ze svých priorit to také deklarovala i skupina G-20 na svém summitu v Soulu v r. 2010. Autor tu podrobně rozebírá jednotlivé oblasti GSFN na národní, regionální a multilaterální úrovni. Na národní úrovni se jedná o devizové rezervy. Vysvětleny jsou motivy jejich akumulace i důvody jejich prudkého nárůstu v posledních letech, dále výhody i nevýhody jejich držby a rovněž i důvody toho, proč nadměrná akumulace rezerv není žádoucí jak z hlediska globálního, tak i z hlediska negativních dopadů na danou zemi. Na regionální úrovni se čtenář má možnost seznámit $\mathrm{s}$ finančními facilitami Evropské unie. V tomto kontextu je velká pozornost věnována Evropskému stabilizačnímu mechanismu. Na multilaterální úrovni je hlavní pozornost zaměřena na MMF, který $\mathrm{v}$ době krize řešil svoji nedostatečnou vybavenost finančními zdroji. Díky tlaku skupiny G-20 došlo ke zdvojnásobení členských kvót a k využívání bilaterálních půjček. MMF též reformoval svoji úvěrovou politiku a zavedl některé úvěrové facility bez následného programu, jenom s ex ante kondicionalitou, což byla téměř revoluce $\mathrm{v}$ jeho dosavadní činnosti.

V navazující části se autor zaměřil na devizové rezervy ČNB, které jsou v současné době v poměru $\mathrm{k}$ počtu obyvatel jedny $\mathrm{z}$ největších na světě. Jejich akumulace ale $\mathrm{z}$ větší části nebyla výsledkem potřeby vytvářet nutné zásoby pro př́ípad krize, ale tyto rezervy vznikaly jako vedlejší nechtěný produkt měnové politiky. Autor to dokumentuje na charakteristice třech období, kdy došlo ke skokovému nárůstu rezerv. Popisuje i oblasti, ve kterých jsou devizové rezervy využívány a jak jsou spravovány. Při správě devizových rezerv a jejich rozdělování na likvidní a investiční tranši vychází ČNB z metodiky MMF. Ten při svých každoročních konzultacích vždy konstatoval, že vývoj rezerv nenarušuje ekonomický rozvoj a finanční stabilitu ČR a v zásadě žádná významná doporučení vůči české straně nevznesl. Nicméně se nabízí otázka, zda tato otevréená devizová pozice ČNB není př́iliš riziková.

Autor se dále zaměřil na charakteristiku facilit Evropské unie, které bychom mohli jako nečlenská země eurozóny v případě potřeby využít. Pokud bychom přijali euro, pak 
bychom se automaticky připojili ke smlouvě o Evropském stabilizačním mechanismu, ze kterého je poskytována finanční pomoc zemím eurozóny. Autor tu věnuje velký prostor charakteristice tohoto mechanismu a podmínkám čerpání finančních prostředků. Jako nečlenská země eurozóny se nebudeme do tohoto mechanismu zapojovat a nebudeme do něj ani přispívat. Nehrozí nám tak automatická povinnost podílet se na tvorbě zdrojů, určených ve prospěch problémových zemí eurozóny. Na druhé straně nemůžeme očekávat stejnou úroveň pomoci jako země eurozóny.

Na multilaterální úrovni je čtenář seznámen s naším př́ispěvkem na posilování vlastních i vypůjčených zdrojů MMF. ČR se vždy podílela na navyšování členských kvót, které tvoří vlastní kapitál MMF. Teoreticky by bylo možné na tomto posilování neparticipovat, ale odmítnout navýšení členské kvóty nebylo s ohledem na naše postavení jako vyspělé ekonomiky a členské země EU prakticky možné, a navíc by hrozilo velké reputační riziko. Při projednávání otázky navýšení kvót MMF jsme však ne vždy podporovali návrhy na nejvyšší navýšení. Možná by bylo zajímavé, kdyby autor uvedl, konkrétní důvody našeho postoje.

Čtenář se může též seznámit se způsobem, jakým se podílíme na půjčkách třetím zemím, což také nebývá běžně publikováno. Na základě rozhodnutí Výkonné rady MMF byla ČR v roce 2000 zařazena do tzv. Plánu finančních transakcí. Tím jsme se připojili k zemím s aktivní spoluúčastí na půjčkách MMF. K zařazení do tohoto mechanismu se nevyžaduje souhlas členské země, ale stabilní platební bilance. Od této chvíle se ČR podílí na půjčkách poskytovaných třetím zemím, aniž by musela tuto aktivitu přerušit, např́klad z důvodu problémů s platební bilancí.

V souvislosti s potřebou posílit likvidní zdroje MMF bylo navrženo uzavírání bilaterálních úvěrových dohod. Zde se mimořádně angažovala Evropské unie, aby ukázala, že je připravena se na tomto posilování podílet. Důvodem byla vysoká úvěrová angažovanost MMF v zemích EU, zejména eurozóny. Přispět musela i Česká republika, a to ekvivalentní částkou podle výše naší kvóty. Zpočátku byl př́istup některých zemí EU včetně ČR, jak uvádí autor, dosti rezervovaný. Nakonec ale převládl pocit solidarity i tlak zemí eurozóny na váhající členy. ČR uzavřela postupně s MMF tři úvěrové bilaterální dohody a po vypuknutí koronavirové krize nás MMF požádal o další dohodu, jejiž platnost by měla skončit v roce 2023.

Autor se tu v souvislosti s tvorbou zdrojů MMF vrací k události z roku 2010, kdy z jednání Evropské rady vyplýval politický závazek vstupu členských zemí EU do „Nové dohody o zápůjčce“" (NAB). Předpokládalo se, že by ČR převedla svůj tehdejší úvěrový bilaterální závazek vưči MMF do této multilaterální úvěrové dohody. Ministerstvo financí připravovalo pro vládu ČR materiál o vstupu ČR do NAB. Nakonec bývalý ministr financí Kalousek rozhodl, že předložení materiálu do vlády bude odloženo. Na základě toho byl MMF informován výkonným ředitelem naší konstituence, že ČR zatím do NAB 
nevstoupí. Autor již nevyhodnocuje, zda nenaplnění politického závazku mělo pro ČR nějaké negativní konsekvence, a ani neuvádí, proč MMF chtěl řešit problém nedostatku zdrojů touto cestou.

Bez zajímavosti není ani historický exkurz do půjček, které ČR od MMF obdržela. Po roce 1989 jsme měli velký zájem na tom, aby Československo obnovilo své členství v MMF. Hned po podpisu smluv ve Washingtonu 14. záři 1990 byla zahájena jednání o ekonomickém programu a finanční pomoci, kterou jsme v té době nutně potřebovali. Jednání proběhla rychle a byla důležitým faktorem úspěšného nastartování naší ekonomické reformy. $\mathrm{V}$ době, kdy nám MMF půjčoval poprvé (následován půjčkami od Světové banky a dalších institucí), jsme ještě nemohli vstoupit na finanční trhy, protože bychom státní dluhopisy bud' neprodali, nebo by byly náklady na jejich umístění př́liš vysoké. Podpora MMF a Světové banky našemu reformnímu programu zvýšila naši kredibilitu natolik, že jsme byli již v roce 1991 schopni vstoupit na soukromé trhy a v roce 1993 na veřejný trh dluhopisů a nebyli jsme nuceni čerpat další oficiální půjčky. I když splatnost dluhu vůči MMF končila až v roce 1999, veškeré půjčky byly předčasně splaceny již v roce 1994.

V úvodní části šesté kapitoly (Měny v mezinárodním měnovém systému) si autor klade otázku, zda může být MMS i nadále založen pouze na dominanci jedné měny - americkém dolaru. Oproti dominanci jedné měny uvádí tř̆i možné alternativy. Systém s více měnami, kde by žádná nebyla dominantní, systém, který by využíval multilaterální měnu SDR nebo novou rezervní měnu $\mathrm{v}$ duchu keynesovského Bancoru. Nicméně autor nepředpokládá, že by dominance dolaru v MMS brzy skončila. K tomu uvádí, že př́padný proces přechodu $\mathrm{k}$ víceměnovému systému by byl postupný a závislý na volném přístupu $\mathrm{k}$ těmto měnám a na ochotě zahraničních agentů vydávat, držet a aktivně obchodovat aktiva denominovaná v těchto měnách na mezinárodních trzích. Zejména během přechodného období by mohlo rozšriření počtu mezinárodních měn vystavit MMS určitému riziku nestability. Proto tento proces by musel být doprovázen užší spoluprací mezi emitenty rezervních měn, aby pomohli zvládnout volatilitu kurzu a kapitálových toků. K tomu autor dodává, že mezi těmito měnami bude určitě i euro.

Šestá kapitola se prioritně zabývá postojem České republiky k přijetí eura. V rámci objektivního popisu všech aspektů přijetí eura jsou uvedeny výhody a nevýhody tohoto kroku, odhady nákladů na přijetí eura, institucionální opatření $\mathrm{k}$ jeho přijetí, stav sladěnosti naší ekonomiky s eurozónou i pohled MMF na přijetí eura. I když se ČR při vstupu do EU zavázala k přijetí eura, v současné době zatím termín stanoven není. Eurozóna se od našeho vstupu výrazně změnila, a proto, jak zdůrazňuje autor kapitoly prof. Helísek, součástí hodnocení, zda euro přijmout, či ne, již nemůže být jenom nominální a reálná konvergence, ale též nové institucionální mechanismy, které v eurozóně po krizi 2008/2009 začaly působit. Na druhé straně však autor uvádí, že je také nutné si uvědomit, že všechny 
nové reformy v eurozóně přispěly $\mathrm{k}$ posílení a odolnosti eura. Přijetí eura je politická otázka, ale naše politická reprezentace není $\mathrm{k}$ rozhodnutí politicky nucena, protože podle průzkumů veřejného mínění je $75 \%$ obyvatelstva proti jeho přijetí. Naopak velká většina firemních managementů je pro jeho rychlé přijetí. V blízkém období se však přijetí eura neplánuje. Nepochybně by bylo zajímavé i žádoucí posoudit, zda při řešení krizí bychom na tom nebyli lépe, nebo naopak hůře, kdybychom euro měli.

Součástí této kapitoly je i samostatná podkapitola o roli SDR v MMS. Tato otázka nabývá vždy na aktuálnosti v krizových obdobích. To se projevilo i po vypuknutí koronavirové krize, když řada členských zemí požádala MMF o schválení nové alokace SDR, která by byla obdobná té z roku 2009. Protože se nepodařilo na jarním zasedání IMFC ve Washington v roce 2020 získat pro novou alokaci podporu, management MMF nyní analyzuje, jak by se daly ve prospěch nejvíce postižených $\mathrm{EMDC}_{\mathrm{S}}$ využít doposud alokovaná SDR. Autor $\mathrm{k}$ tomu dodává, že $\mathrm{v}$ této oblasti patří Česká republika $\mathrm{k}$ obezřetným státům, které kromě kladů upozorňují i na všechna rizika spojená s morálním hazardem a nebezpečím inflace.

Poslední sedmá kapitola ukazuje, jak Česká republika realizuje svůj dohled a regulaci a jakým způsobem spolupracuje $\mathrm{v}$ této oblasti na mezinárodní úrovni. Náš prínos je zejména v tom, že udržujeme český finanční systém zdravý, stabilní a důvěryhodný. K tomu přispívá i implementace doporučovaných reforem a mezinárodních standard do našeho dohledu a regulace. Pro dokreslení autor uvádí hodnocení našeho finančního sektoru ze strany MMF. Poslední část v této kapitole se věnuje opatřením, která príijala ČNB v boji s koronavirovou krizí.

Celkově lze říci, že hodnocená publikace reaguje na současné klíčové problémy globální finanční a měnové stability. Její bezprostřední aktuálnost je umocněna právě probíhající koronavirovou krizí, která bude mít nesporně dopady do finanční a hospodářské krize globální povahy. Pro svou vysokou odbornou úroveň se předkládaná publikace může stát vhodným doplňkovým studijním materiálem nejen pro studenty vysokých škol ekonomického zaměření, ale může být prínosná i široké odborné veřejnosti, jejíž zájem se orientuje na problematiku mezinárodních vztahů a světové ekonomiky. K silným stránkám knihy patří bezpochyby historický prristup autora $\mathrm{k}$ popisované problematice, který umožňuje čtenáři lépe pochopit souvislosti mezinárodních reformních kroků a postoje České republiky. Nelze vyloučit, že kniha bude po čase vyžadovat aktualizaci a doplnění. V rychle se měnící globalizované době to snad ale jinak ani není možné. Cenné na knize je to, že autor v ní z velké části čerpá z osobních zkušeností a uvádí tu skutečnosti, které nejsou obecně známy.

Poznámka: Autorem kapitoly VI je prof. Ing. Mojmír Helísek, CSc., Vysoká škola finanční a správní, a.s. Tato kapitola vznikla v rámci institucionální podpory na dlouhodobý koncepční rozvoj výzkumné organizace VŠFS. 